\title{
コンクリート床下地の表層部品質に関する指標のあり方 \\ CONCEPT OF QUALITY INDEX ON SURFACE LAYER OF CONCRETE GROUND WORK
}

横山 裕*, 横井 健**

Yutaka YOKOYAMA and Takeshi YOKOI

\begin{abstract}
There is no end of poor surface layers of concrete ground works with insufficiency of the execution circumstances and using soft concrete. In this case, even highly efficient finishing materials cannot make floors come up to the requirement performance. Essentially, it is the reason which is given no clarification to the quality due to the characteristics of concrete and the execution circumstances.

This report describes results of field investigations on the characteristics of concrete and the execution circumstances. It shows the concept of the quality index on the surface layers of concrete ground works with giving an instance.
\end{abstract}

Keywords : concrete ground work, quality of surface layer, index, workability, execution circumstance, field investigation コンクリート床下地，表層部品質，指標，施工性，施工条件，実状調査

\section{1.はじめに}

建築を構成する床，壁，屋根などの各部位のうち、床は、建築物 内の人間や什器・備品, 各種機器などが絶えず接していることから、 日常の安全性，居住性，使用性などの観点からより重要な部位とい える。床は、一般に、下地層と、場合によって設けられる何層かの 中間層、および仕上げ層から構成されており、床の性能には、仕上 げ層のみでなく、当然のことながら下地層や中間層が大きく影響す る。多くの場合、下地層（以降、“床下地”と記す）にはコンクリート やそれに類する材料が用いられるが、床下地に用いられるコンクリー トの上面は、床下地底面や壁側面などの型枠などに接している面と 異なり、打設から養生にかけての施工の過程で、通常「ならし」，「押 え」などと称する上面仕上げ作業を施す必要がある。また、養生の際 も、より多くの措置が必要である。そして、これらの作業, 措置の 良否によって床下地表層部の品質は大きく変化することが知られて いる。

ところが、近年、工期の短縮や工費の削減に伴う労力の低下など の影響で、表層部品質が劣悪な床下地が㐱く出現しており、高い性 能を有する中間層，仕上げ層（以降、あわせて“仕上げ材”と記す） を選択したにもかかわらず、䇋工後に所期の性能が得られず問題と なる事例が多発している。このような問題を未然に防ぐためには、 床下地の表層部品質と仕上げ材施工後の床の性能との関係を明確に するとともに、施工に要する労力や荃生期間などの施工条件の要因
を取り込んだ床下地の表層部品質に関する指標が必要と思われる。 本報は、実際の現場におけるフレッシュコンクリート（以降、“生 コン”と記す)および施工条件の現状や床下地表層部の品質上の問題 点およびその発生原因について調查するとともに、コンクリート床 下地の表層部品質に関する指標のあり方を提案し、さらにこの提案 に沿った指標の具体例を提示した経過，結果を述べるものである。 なお、本報は、日本建築学会大会での発表1) 3)に、さらなる検討 を加えたものである。

\section{2. 研究の目的, 範囲}

本研究は、コンクリート床下地の表層部品質に起因する問題が発 生する背景を明らかにしたうえで、コンクリート床下地の表層部品 質に関する指標のあり方を提案することを目的としている。ここで、 本研究はあくまでも指標のあり方を提案するものであり、8. で提示 する具体例はあくまでも提案した指標のあり方に対する理解を深め るためのものであること、本研究での提案に基づいた実用性のある 指標の具体的提示は本研究の範囲外としていることを強調する。 本研究で対象とする生コンは、とりあえずごく一般的な普通コン クリート(普通ポルトランドセメント, AE減水剤標準形使用) とする。 また、対象とする施工法は、従来から現場で行われているごく一般 的な施工法とする。具体的には、コンクリートポンプなどを用いて 生コンを型枠内に投入し、人力もしくはバイブレータ，機械ごてな
* 東京工業大学大学院理工学研究科建築学専攻 助教授.工博

** 東京工業大学大学院

21世紀 COE 研究員リサーチアシスタント・修士(工学)
Assoc. Prof., Dept. of Architecture and Building Eng., Graduate School of Science and Eng., Tokyo Institute of Technology, Dr. Eng.

21st Century COE Researcher, Graduate School, Tokyo Institute of Technology, M. Eng. 
どの小型施工機械にて荒ならし，締固めおよび上面仕上げ作業など を行う方法とする。なお、他の生コン，施工法を対象とした検討は、 本研究以降の課題とする。

\section{3. 既往の研究}

コンクリートおよびコンクリート建築物の品質や、生コンの特性 との関係に関する研究は、これまでに数多くなされている。しかし、 床下地の表層部品質を対象とした研究例は比較的少なく、さらに施 工条件の要因を取り込んだ研究例としては、小野，地䈨，添田の研 究4)以外見あたらない。

小野らは、ヒアリング調查により、床下地コンクリート施エにお ける計画，管理上の不適正が原因で発生する下地面の代表的な欠陥 として、凹凸，表面強度不足，雨だれ跡の3項目を抽出している。さ らに、不適正な施工条件を1〜2段階設定し、その条件で施エした場 合の凹凸，表面強度，雨だれ跡に関するデータを適正な施工条件で 施工した場合と比較する検証実験を行っており、床下地の表層部品 質に及ぼす施工条件の影響の大きさを実験的に明らかにするととも に、施工条件の要因を取り込んだ研究の必要性を強調している。本 研究は、小野らの研究成果を受けて、施工条件の要因を取り込んだ 表層部品質に関する指標について検討するものである。

\section{4. 施工管理担当者を対象とした生コンのかたさに関する実験}

本節では、奏際に現場で打設されている生コンの実状を把握する 目的で行った、施工管理担当者に生コンのかたさの適否や打設経験 の有無を判断させる実験の経過, 結果を述べる。

\section{1. 矛借調査}

コンクリート工事の最終責任者であり、品質と施工性を勘案した 総合的な判断を下す立場にある施工管理担当者を対象に、予備調査 をヒアリング形式で実施した。この調査は、施工管理担当者は、施 工の際、生コンのかたさについてどのような対応をしているのかを 把握するとともに、実際の現場で生コンのかたさをどのように判断 しているかを抽出し、実験の基礎資料とすることを目的としている。

表 1 に本調查と実験の検査員の概要を示す。検查員の選定にあたっ ては、コンクリートエ事の管理に豊富な経験を有すること、様々な 担当地域から選定することなどに留意した。なお、本調查と実験で は、当初は検查員数を特定せず、1名づつ調査，実験を積み重ね、安 定した結果が得られた時点で終了することとした。その結果、4名が

\section{表 1 予備調査およひ实験の抰査員の概要}

\begin{tabular}{|c|c|c|c|}
\hline 哖䑪 & 坼原 & 担筜地域 & 経呀年数 \\
\hline 36歳 & 総合建設業 & 九州 & 10 年 \\
\hline 34歳 & 総合建設業 & 関東 & 10年 \\
\hline 29歳 & 総合建設業 & 東海 & 7年 \\
\hline 36歳 & 総合建設業 & 関西 & 8年 \\
\hline
\end{tabular}

表 2 予供調査の筫問およひ代表的な回答

\begin{tabular}{|c|c|}
\hline 賈閣 & 代表的な回答 \\
\hline 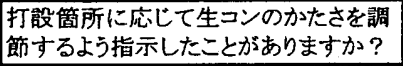 & $\begin{array}{c}\text { ある } \\
\text { (全員が「ある」と回答) }\end{array}$ \\
\hline 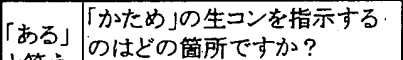 & $\begin{array}{l}\text { 吹き出しのある箇所(階段など) } \\
\text { 勾配のある箇所(屋根など) }\end{array}$ \\
\hline 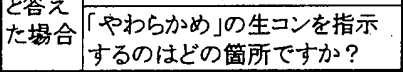 & 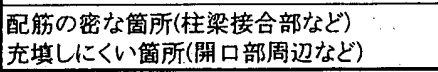 \\
\hline $\begin{array}{l}\text { 生コンのかた } \\
\text { か? }\end{array}$ & 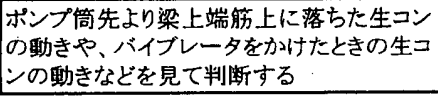 \\
\hline
\end{tabular}

終了した段階で、いずれの検查員からもほぼ同様の結果が得られた ことから、これ以上検查員を増やしても結果は大きくは変化しない と判断し、終了とした。

質問および代表的な回答を表 2 に示す。調查の結果、いずれの施 工管理担当者も、設計図書などに規定されたスランプによる管理と は別に、打設䈏所に态じて生コンのかたさを微妙に調節しているこ とがわかった。また、施工管理担当者は、「ポンプ筒先より梁上端筋 上に落ちた生コンの動き」や「バイブレータをがけたときの生コンの 動き」などを見て、生コンのかたさを判断していることがわかった。

\section{2. 実験方法}

4.1.の予備調查で対象とした4名を検査員として別々に実験室に招 き、かたさが異なる種々の生コンを試料として提示し、実際に打設 するとした場合のかたさの適否や打設経験の有無を判断させる実験 を行った。

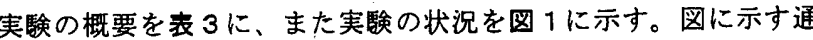
り、実験は、模擬简先や配筋を施した模擬梁型枠を用い、「ポンプ筒 先より梁上端筋上に落ちた生コンの動き」や「バイブレータをかけた ときの生コンの動き」を再現して検查員に見せ、表了に示す(1)（5)(質 問1)および(〜C(質問2)のいずれかの判断を求める方法で行った。 なお、検査員には、スシンプ18cmの普通コンクリートと規定された 工事を想定したうえでの判断を求めた。

試料とした生コンは、表 3に示す通り検査員1名あたり 24 種とし、 水セメント比 $55 \%$, 細骨材率 $46 \%$ で単位水量のみを変化させ、かた さを変化させた。また、検査員1名あたり3〜4種の試料は、しばしば

表 3 生コンのかたさに関する実験の概要

\begin{tabular}{|c|c|c|c|}
\hline & \multicolumn{3}{|c|}{$\begin{array}{l}\text { あなた自身の、スランプ18cmと規定された工事での生コン打設業務か } \\
\text { ら得た経験と照らし合わせて、以下質問に抢答え下さい } \\
\end{array}$} \\
\hline 䈯 & \multirow{5}{*}{$\begin{array}{l}\text { 質問1:この「かた } \\
\text { さ」, 「やわらか } \\
\text { さ」の生コンは、打 } \\
\text { 設作業および品質 } \\
\text { の観点から }\end{array}$} & & かたすぎて適当でない \\
\hline 5 & & & $\begin{array}{l}\text { 階段，勾配屋根など、かためが必要な箅所に適 } \\
\text { 当である }\end{array}$ \\
\hline$u$ & & (3) & 一般的な箇所に適当である \\
\hline & & & $\begin{array}{l}\text { 柱梁接合部，開口部周辺など、かたいと特に打 } \\
\text { 段しにくい籄所に適当である }\end{array}$ \\
\hline 笔 & & & やわらかすぎて適当でない \\
\hline 9 & \multirow{3}{*}{ 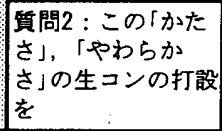 } & (A) & 日常的に行っている \\
\hline 3 & & & 日常的ではないが、行ったことがある \\
\hline & & (C) & 行ったことがない \\
\hline & \multicolumn{2}{|c|}{ 試料数(蚞查員 1 名あたり) } & 24種(ちち3〜4種はシャブコン) \\
\hline \multirow{7}{*}{ है } & \multicolumn{2}{|l|}{ セメント } & 普通ポルトランドセメント \\
\hline & \multicolumn{2}{|l|}{ 水セメント比 } & $55 \%$ (シャブコンを除く) \\
\hline & \multicolumn{2}{|l|}{ 単位水量 } & \begin{tabular}{|l}
$157 \sim 191 \mathrm{~kg} / \mathrm{m}^{3}$ \\
シャフコン: 单位水 $166 \mathrm{~kg} / \mathrm{m}^{3}$ の調合に、, \\
$\quad$ 単位水量の $20 \%, 25 \%$ 水を追加投入
\end{tabular} \\
\hline & \multicolumn{2}{|l|}{ 練骨材率 } & $46 \%$ \\
\hline & \multicolumn{2}{|l|}{ 混和鼡 } & AE减水削標哖形 \\
\hline & \multicolumn{2}{|l|}{ スランプ } & $4.9 \sim 23.3 \mathrm{~cm}$ \\
\hline & \multicolumn{2}{|l|}{ スランプフロー } & $20.1 \sim 63.0 \mathrm{~cm}$ \\
\hline
\end{tabular}

その他、生コンの印象など自由回答も求また

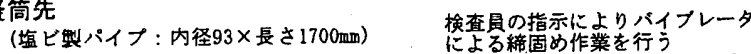
生コンを充填

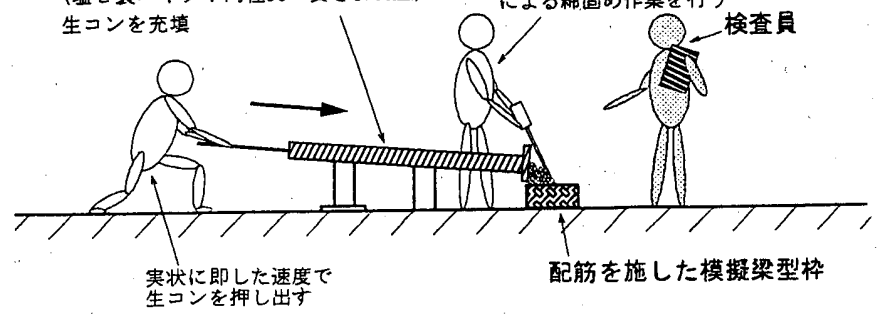

図 1 実験の状況 

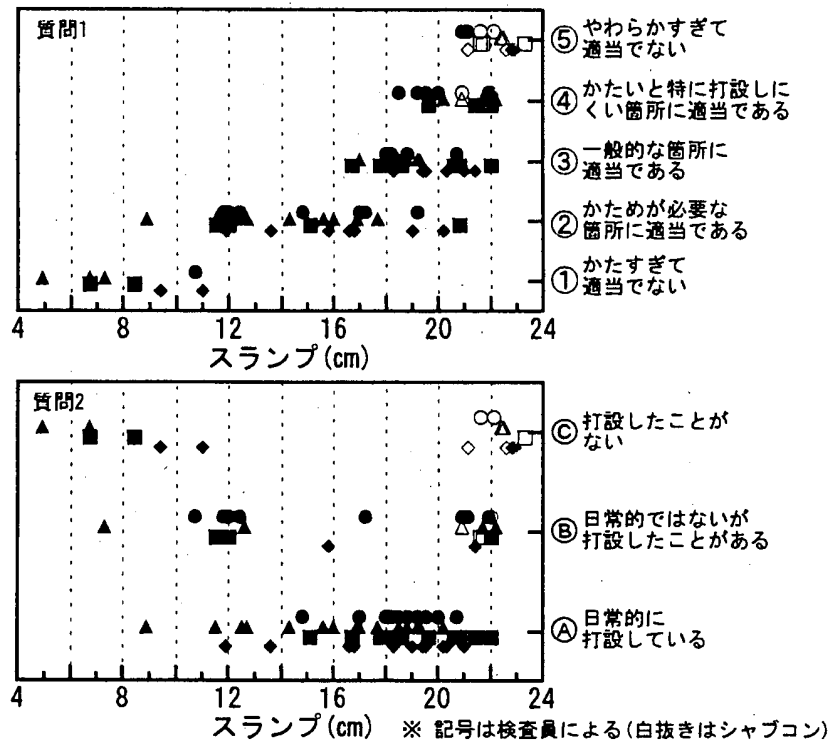

図 2 娭査員の回答とスランプの関係

問題となる不法加水を再現する目的で、基本的な調合に水のみを過 剩に加えたいわゆる「シャブコン」とした。

\section{3. 実験経過、結果}

実験は、1999年6〜10月の間の盛夏を避けた時期に実施した。検査 員が一つの試料の判断に要した時間は、3分程度であった。また、実 験と並行して、試料とした生コンのスランプなどを、検査員から見 えない場所で測定した。

図 2 に、検査員の回答とスランプの関係を示す。図の記号は、検

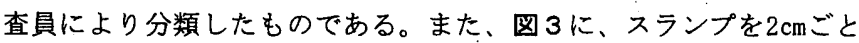
に区切り、それぞれの範囲内の陚料に対する回答の割合を求めた結 果を示す。図 2，3の上図より、スランプ18cmと規定された工事で「(3) 一般的な籄所への打設に適当」と判断された試料の多くはスランプ 17 〜22cmに分布していること、特にスランプ18〜20 cmの範囲では大半 の試料が(3)と判断されていることがわかる。また、「(4) かたいと特 に打設しにくい䉯所に適当」と判断された試料はスランプ19〜 $22 \mathrm{~cm}$ 程 度に分布しており、スランプ20〜 22cmの範囲でも「(5) やわらかすぎ て適当でない」と判断される割合はそれほど多くはないことがわか る。さらに下図より、スランプ $22 \mathrm{~cm}$ 程度でも「®日常的に打設して いる」と判断されている試料があることがわかる。これらの結果から、 (3)，(4)に該当する箅所に実際に打設されている生コンのスランプは、 ポンプ圧送などによるロスを加味して、荷卸し時に18～22 cm程度と みなすことができる。

なお、JIS A 5308(レディーミクストコンクリート)では、スラン プ18cmの場合 $2.5 \mathrm{~cm}$ の誤差が認められているが、上述の荷卸し時の スランプ18〜22cm程度という実状と比較すると、JISでは誤差として 定められた籁囲が、実際には施工管理担当者によって許容範囲と読 み替えられている現状がうかがえる。

なお、「シャブコン」に対しては、ほとんどの場合、検查員は「(5) やわらかすぎて適当でないおおよび「C 打設したことがない」と判断 した。

\section{4. 考察}

一般建築物のコンクリートエ事には通常スランプ $18 \mathrm{~cm}$ 以下の生コ ンを用いるよう各種仕様書に規定されているが、実際には、施工管 理担当者の判断によりかたさの微調整が指示されており、一般的な
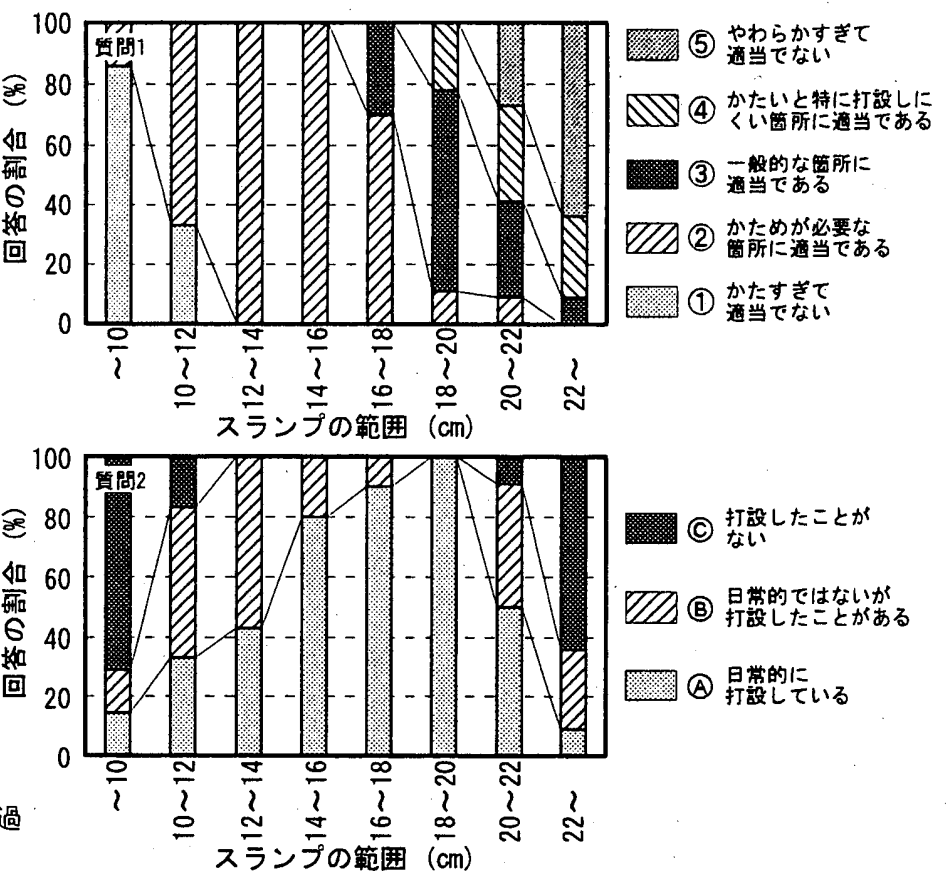

図 3 スランプことの回答の割合

箘所ではスランプ $18 \mathrm{~cm}$ よやわらかい生コンが打設されている現状 が明らかとなった。この結果は、施工管理担当者が打設の際最も重 要視しているのは、配筋の密な䇢所や開口部周辺などにいかに確実 に充填するかであることを、示唆しているといえる。これに対し、 比較的打設しやすい床下地への打設時には、かたさの微調整などは 一般的には行われておらず、やわらかい生コンがそのまま打設され ている。そして、このことが、表層部品質が劣覀な床下地が多く出 現している一因となっていると想定される。

5. コンクリート床下地表層部の品筫上の問題点とその原因に関する調査

本節では、上面仕上げ作業担当者を対象に、床下地表層部の品質 上の問題点や、各問題点と施工上の原因の因果関係、およびその施 工上の原因がどのような施工条件の不備に起因するのかを、具体的 に調查した経過，結果を述べる。

\section{1. 調查方法}

調査は、熟練上面仕上げ作業担当者5名を研究室に招き、ヒアリン グ形式で実施した。表 4 に調査対象者の概要を示す。具体的には、 表 5 に示す質問文にしたがって、完成後の床下地表層部の品質上の 問題点 (笛問1)を抽出し、さらに各問題点と施工上の原因の因果関倸 (筫問2)、およびその施工上の原因がどのような施工条件の不備に起 因するものか(筫問3)を調查した。

表 4 調查対象者の概要

\begin{tabular}{|c|c|c|}
\hline 年粭 & 担当作業: & 経酸每数 \\
\hline 59歳 & 上面仕上げ作業をはしめ左官作業全般 & 34年 \\
\hline 50歳 & 上面仕上げ作業，溆り本施工作業 & 18年 \\
\hline 63歳 & 上面仕上げ作業 & 39年 \\
\hline 56歳 & 上面仕上げ作業をはじめ左官作業全般 & 36年 \\
\hline 60歳 & 上面仕上げ作業，左官用化学真品取极 & 15年 \\
\hline
\end{tabular}

表 5 品質上の問題点とその原因に関する調查の筫問文

\begin{tabular}{|c|c|}
\hline 筫問 & 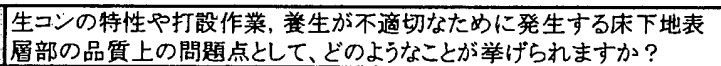 \\
\hline 幊問2 & 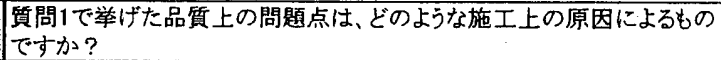 \\
\hline 覓問 3 & $\begin{array}{l}\text { 賈問2で挙げた施工上の原因は、どのような施工条件の不偏に起因す } \\
\text { るものですか？ }\end{array}$ \\
\hline
\end{tabular}




\section{2. 調査経過、结果}

調査は、2000年6月に、調查対象者5名と著者らの合議形式で赛施 した。調査に要した時間は、約2時間であった。

調查結果をまとめて表 6 に示す。本調查では、結果の分析にあた り、調査対象者全員の賛同が得られていることを基準にした。すな わち、表中に举げられた項目は、いずれも「品質上の問題点」，「施 工上の原因」，「施工条件の不備」として指摘，抽出され全員の賛同 が得られた項目であり、また○が付された組み合わせは、因果関俰 があるとして全員の賛同が得られた組み合わせであることを表す。 なお、本調査において、調查対象者 5 名の判断が最終的に分かれたこ とはなかった。

表に示す通り、床下地表層部の主な品質上の問題点として、「凹凸・ 不陸」;「表面強度不足小「水分量過多」，「ひび割れ発生」の4点が抽 出された。このうち「凹凸・不陸」,「表面強度不足」、「ひび割れ発生」 には、練混ぜ開始から打設までの時間長すぎ」、「締固め不十分」,「な らしを)浮き办が出る前に終了しない」なと、多くの施工上の原因が 影響していることがわかる。一方、「水分量過多」の原因としては、「凝 結前に散水する」や「十分乾燥しないうちに仕上げ材施工開始」などが 举げられている。さらに、これらの根元である施工条件の不備とし ては、「打設速度速すぎ」，各行程の作業担当者の「技能・人員不足」 および各種「養生期間不足」が多く指摘されており、施工にかける労 カの不足や養生のための工期の不足が、様々な観点から表層部の品 質上の問題点に媣く関与している現状がうかがえる。

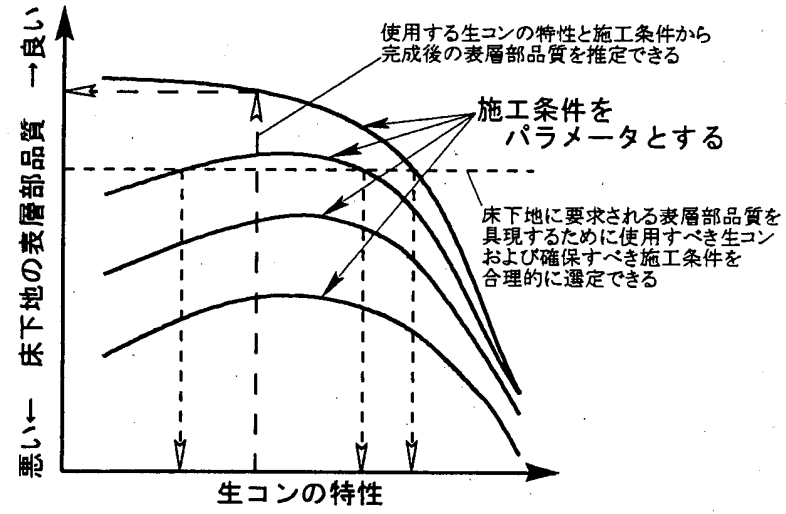

図 4 コンクリート床下地の表層部品質に関する指標の例

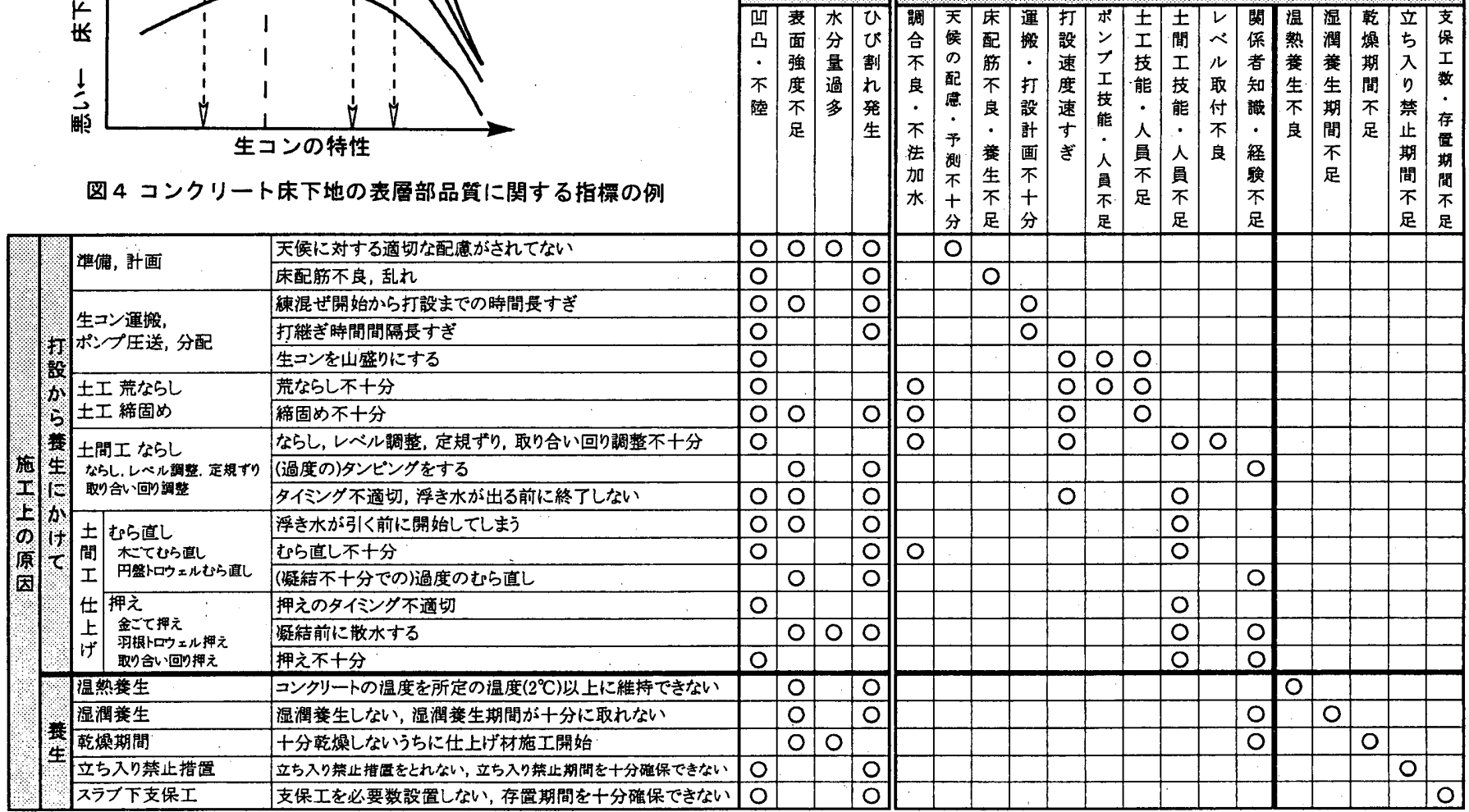

なお、以上の結果は、3.で述べた小野らの調查結果4)と大きくは 異ならない。（ただし、小野らが提示している「雨だれ跡」は、本研究 では「天候の配慮・予測不十足」が原因の「凹凸・不陸」および「表面強 度不足」に包含されるものとしている。

\section{6. コンクリート床下地の表層部品質に関する指摽のあり方の提案}

5. で述べた通り、床下地の表層部品質に関する問題発生の大きな 原因として、労力不足や養生期間不足などの施工条件の不備が举げ られる。また、4.で述べた通り、やわらかい生コンの使用が床下地 表層部の品質上の問題の一因となっていることも予想される。この ような実状が容認されている背景として、どのような特性の生コン を使用し、どのような条件で施工すれば、どの程度の表層部品質の 床下地ができるかが明らかになっていないことが挙げられる。すな わち、图 4 に例示するような、生コンの特性および施工条件と施工 後の床下地の表層部品質の関倸を定量的に表す指標を提示し、施工 管理担当者をはじめとする様々な関係者が床下地の表層部品質の重 要性を認識し、施工時に十分な配慮をするための資料とする必要が あると考えられる。

图 4に例示した指標は、使用する生コンの特性と施工条件から完 成後の床下地の表層部品質を推定できるばかりでなく、逆に床に要 求される性能から床下地に要求される表層部品質を設定し、この品 質を具現するために使用すべき生コンおよび確保すべき施工条件を 合理的に選定することができる。すなわち、要求に見合った材料お よび施工条件の選定を可能とし、さらには施主や設計者に対し必要 労力を明示し確保を促すための有勃な資料となるものであり、性能 の時代における施工に必要な指標のあり方を示すものといえる。

なお、図4ははあまでも例であり、指標の体裁はこの他様々なも のがあり得ることを付け加える。

表 6 品筫上の問題点とその原因に関する調査結果

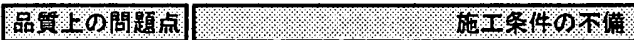


7. コンクリート床下地の施エ条件の実状に関する調査

本節では、6.で提案した指標を具体的に例示する際必 要となる数段階の施工条件を設定するための基礁资料を 得る目的で行った、実際の現場におけるコンクリート床 下地の施工条件の実状に関する調查経過，結果を述べる。

\section{1. 施工管理担当者を対象とした調査}

\subsection{1 調查方法}

はじめに、施工管理担当者を対象とした、コンクリー ト工事全般に関する実状調查を、アンケート形式で実施 した。本調查では、5.で施工条件の不備として指摘され た事項を参考に、1日あたりの生コン打設量，作業人員数 および作業方法，悪天候に対する措置，各種養生の措置・ 期間などに関する(1)〜 (18)の項目（表 7参照)を設定し、 下記の3種の床下地施工を想定した場合の回答を求めた。

ア：工場，倉庫などの平戸間を施工する場合

$1:$ 事務所などの構造スラブを施工する場合

ウ：スタジオ，病院の床など、高い表層部品質が要求さ れる構造スラブを施工する場合

調查対象者は、経験豊富な施工管理担当者とし、所属 する組織や勤務地域が様々となるよう選定した。

\subsection{2 調査経過, 結果}

調查は、2000年8月に実施した。アンケートは、対象者 に事前に協力を申し入れたうえで用紙を送付する方法で 行った。当初、用紙を総合建設業 8 社 14 名に送付し回答を 得たが、より詳細な数值を把握する必要があると思われ た項目 (8)〜(11)に関しては追加調査を実施し、さらに 18名から回答を得た。

調査結果をまとめて表 フに示す。表には、全回答の中 から、回答数の多かった代表的な回答、もしくは籁囲を 示した。

\section{2. 上面仕上げ作業担当者を対象とした調查 \\ 7.2. 1 調查方法}

7.1.につづき、上面仕上げ作業担当者を対象とした、 個々の具体的な作業の施工条件に関する実状調査を、ア ンケート形式で実施した。本調查では、それぞれの作業 の作業人員数，作業員 1 人ありの作業面積，使用する道具，作業方 法などに関する(1)〜 (10)の項目 (表 8参照)を設定し、普通の天候の もと一般的な厚さ，配筋の構造スラブを金ごて仕上げで施工する場 合を想定した回答を求めた。ここで、本調查では、現在実際の現場 で行われている施工条件の範囲や、上面仕上げ作業担当者が本来必 要と考える施工条件の程度などが明らかとなるよう、

i：『今まで見聞き，あるいは体験した中で、最も劣悪だった』とい う施工条件 (劣悪な条件)

ii：『最近ではこの程度が一般的だ』という施工条件(一般的な条件)

iii：『これだけの条件が整えば表層部品質の良い床下地を施工するの

に十分だ』という施工条件(理想的な条件)

の3段階の施工条件について回答を求めた。

調査対象者は、比較的規模の大きい工事で床下地施工を請け負う 左官業者の上面仕上げ作業担当者とした。

また、アンケートを補完する目的で、各作業に適切な作業時間帯
表 7 施工管理担当者を対象とした実状調査結果

\begin{tabular}{|c|c|c|c|}
\hline & $\mathcal{P}$ & 1 & ウ \\
\hline 項目 & $\mid \begin{array}{l}\text { 工埸，合速などの平土問を } \\
\text { 施工する埸合 }\end{array}$ & $\begin{array}{l}\text { 事務所などの䒽造スラブを施 } \\
\text { エする坦合 }\end{array}$ & 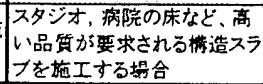 \\
\hline $\begin{array}{c}\text { 寒中に㧍ける } \\
\text { 打嘬作業時の措置 }\end{array}$ & 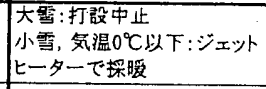 & 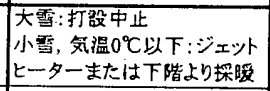 & 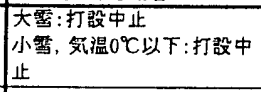 \\
\hline $\begin{aligned} \text { 喜中心 } \\
\text { 打鄙作業 }\end{aligned}$ & 何の措置ととらない & 何の措置もとらない〜散水 & 散水＋土問工增員 \\
\hline $\begin{array}{c}\text { 雨中における } \\
\text { 打設作業時の措置 }\end{array}$ & $\begin{array}{l}\text { 大雨: 打設中止 } \\
\text { 小雨, 打設中の降雨: シート } \\
\text { 羔生, コン天下げ後日補修, } \\
\text { 强度増スランプ下代の等の措 } \\
\text { 置あるいはそれらの組合せ }\end{array}$ & 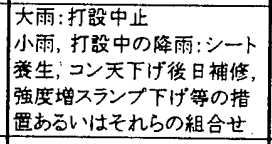 & $\begin{array}{l}\text { 大雨: 打設中止 } \\
\text { 小雨, 降雨の可能性がある } \\
\text { 日:打钤中止 }\end{array}$ \\
\hline $\begin{array}{l}\text { 强風中 } \\
\text { 打設作業 }\end{array}$ & 何の措置もとらない & 何の措置もとらない & 散水＋土間工增員 \\
\hline $\begin{array}{c}\text { 作業者, ポンプ配管 } \\
\text { に対する } \\
\text { 床配筋の業生 }\end{array}$ & $\begin{array}{l}\text { 作業者:メッンュロート，足場 } \\
\text { 板等使用 } \\
\text { 配管:配管用チェーン付馬, } \\
\text { 古タイヤ等使用 }\end{array}$ & $\begin{array}{l}\text { メシシュロート，足坦 } \\
\text { 管用チェーン付馬， } \\
\text { 等使用 }\end{array}$ & $\begin{array}{l}\text { 作業者:メッシュロード，足㙛 } \\
\text { 板等使用 } \\
\text { 配管: 配管用チェーン付馬, } \\
\text { 古タイヤ等使用 } \\
\end{array}$ \\
\hline $\begin{array}{c}\text { 生コンの } \\
\text { 練り混せ開始から } \\
\text { 打毂了ま終了まで } \\
\text { の時間 } \\
\end{array}$ & $\begin{array}{l}\text { 時間超過が管理者の䓀任: } \\
\text { ポンプ代送に支障がある場 } \\
\text { 合打設しないい }\end{array}$ & $\begin{array}{l}\text { 時間超過が管理者の吉任: } \\
\text { ポンブ送に支障がある埸 } \\
\text { 合打設しない }\end{array}$ & 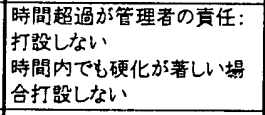 \\
\hline $\begin{array}{c}\text { 生コンの } \\
\text { 打継ぎ時間間隔 }\end{array}$ & $\begin{array}{l}\text { 時間超過が管理者の盲任: } \\
\text { 何の措㯰もとらない }\end{array}$ & $\begin{array}{l}\text { 時間超過が管理者の青任: } \\
\text { 何の措置もとらない } \\
\text { 〜バイプータ等で十分締 } \\
\text { 茝め一体化 } \\
\end{array}$ & 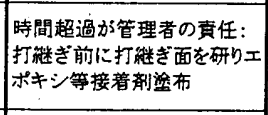 \\
\hline $\begin{array}{c}\text { 生コン1日あたり } \\
\text { 打設量 } \\
\text { 打設速度 }\end{array}$ & $\begin{aligned} & \text { 打钤量: } 300 \mathrm{~m}^{3} \\
& \text { 床面稘: } 800 \sim 1000 \mathrm{~m}^{2} \\
&\left(1000 \mathrm{~m}^{2}\right) \\
& \text { 打設速度: } 20 \sim 40 \mathrm{~m}^{3} / \text { 時 } \\
&\left(30 \sim 40 \mathrm{~m}^{3} / \text { 時 }\right) \\
& \text { 床面皘: } 200 \mathrm{~m}^{2} / \text { 特 } \\
&\end{aligned}$ & $\begin{aligned} & \text { 打設量: } 300 \mathrm{~m}^{3} \\
& \text { 床面稙: } 500 \sim 1000 \mathrm{~m}^{2} \\
&\left(1000 \mathrm{~m}^{2}\right) \\
& \text { 打設速度: } 30 \sim 50 \mathrm{~m}^{3} / \text { 時 } \\
&\left(30 \mathrm{~m}^{3} / \text { 時 }\right) \\
& \text { 休面積: } 200 \mathrm{~m}^{2} / \text { 時 } \\
&\end{aligned}$ & $\begin{aligned} & \text { 打設量: } 250 \sim 300 \mathrm{~m}^{3} \\
& \text { 床面矰: } 400 \sim 600 \mathrm{~m}^{2} \\
&\left(400 \mathrm{~m}^{2}\right) \\
& \text { 打設速度: } 20 \sim 40 \mathrm{~m}^{3} / \text { 時 } \\
&\left(30 \mathrm{~m}^{3} / \text { 時) }\right. \\
& \text { 床面馧: } 50 \sim 200 \mathrm{~m}^{2} / \text { 時 } \\
&\end{aligned}$ \\
\hline $\begin{array}{c}\text { ポンブー台あたり } \\
\text { ポンプエ人員 } \\
\end{array}$ & 2 3名 & 2 -3名 & 2〜3各 \\
\hline $\begin{array}{c}\text { ポンプー台あたり } \\
\text { 土工人員 }\end{array}$ & $\begin{array}{l}\text { 荒ならL: } 1 \sim 3 \text { 名(1〜2名) } \\
\text { 締固め: } 1 \sim 3 \text { 名(1〜2名) } \\
\text { その他: } 0 \sim 1 \text { 名 }\end{array}$ & $\begin{array}{l}\text { 荒ならし: } 1 \sim 3 \text { 名( } \\
\text { 締固め: } 1 \sim 48 \text { 名( } \\
\text { その他: } 0 \sim 2 \text { 名( }\end{array}$ & $\begin{array}{l}\text { 荒ならし: } 1 \sim 4 \text { 名(2名) } \\
\text { 締固め: } 2 \sim 4 \text { 名 } \\
\text { その他: } 0 \sim 3 \text { 名(1〜2名) } \\
\end{array}$ \\
\hline $\begin{array}{c}\text { 土間工一人あたり } \\
\text { 仕上げ面糟 } \\
\end{array}$ & $100 \mathrm{~m}^{2} / 人$ & $\begin{array}{c}60 \sim 150 \mathrm{~m}^{2} / 人 \\
\left(100 \mathrm{~m}^{2} / \text { 人) }\right.\end{array}$ & $\begin{array}{c}40 \sim 100 \mathrm{~m}^{2} / \hat{人} \\
\left(60 \sim 100 \mathrm{~m}^{2} / \hat{\Lambda}\right) \\
\end{array}$ \\
\hline レベルの出し方 & $\begin{array}{l}\text { レベル筋あるいは } \\
\text { レーザーレベルによる } \\
.\end{array}$ & レーザーレ & 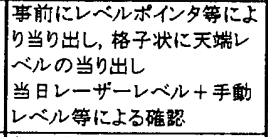 \\
\hline $\begin{array}{c}\text { 寒冷期の温熟養生 } \\
\text { 措置，期間 } \\
\end{array}$ & $\begin{array}{l}\text { 気温 } 0^{\circ} \mathrm{C} \text { 以下:シート養生あ } \\
\text { るいは探暖(1日程度) }\end{array}$ & $\begin{array}{l}\text { 気温 } 0{ }^{\circ} \mathrm{C} \text { 以下:シート養生あ } \\
\text { るいは探暖(1 日程度) }\end{array}$ & 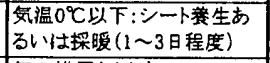 \\
\hline 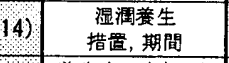 & 何の措置もとらない & 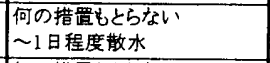 & \begin{tabular}{|l} 
何の措置しとらない \\
$\sim 5$ 日程度散水+シート養生
\end{tabular} \\
\hline $\begin{array}{l}\text { 生中の立ち入り } \\
\text { 禁止措遭, 期間 }\end{array}$ & $\begin{array}{l}\text { 何の措蹎もとらない〜1日程 } \\
\text { 度軽作業以外立ち入り禁止 }\end{array}$ & $\begin{array}{l}\text { もとらない〜1日程 } \\
\text { 以外立ちスり禁止 }\end{array}$ & $\begin{array}{l}1 \sim 2 \text { 日程度一切立ち入り禁 } \\
\text { 止 }\end{array}$ \\
\hline $\begin{array}{c}\text { スラプ下支保工 } \\
\text { 砓置間隔 } \\
\end{array}$ & - & 0 1800mm程度 & 600 900mm程度 \\
\hline $\begin{array}{c}\text { スラブ下支保工 } \\
\text { 存置期間 } \\
\end{array}$ & - & 7〜28日程度(28日) & 28日程度 \\
\hline $\begin{array}{c}\text { 仕上げ材施工開始 } \\
\text { までの短燥期間 }\end{array}$ & 7〜28日程度 & 7〜28日程度(21〜28日) & 21 2 28日程度 \\
\hline
\end{tabular}

※括弧中の值は回答の最頻俌を表す

や作業効率(作業員1人が1時間あたりに行う作業面積)に関するヒア リング調查を、数名の熟練上面仕上げ作業担当者を対象に実施した。

\section{2.2 腤查経過，結果}

アンケート調查は、2001年6月に実施した。アンケート用紙を日本 左官業組合連合会を通じて77名に送付し、30名から有効回答を得た。 また、ヒアリング調査は、アンケート調査結果の集計後に数名の熟 練上面仕上げ作業担当者を対象に実施した。

調査結果をまとめて表 8 に示す。表には、全回答の中から、回答 数の多かった代表的な回答、もしくは範囲を示した。

なお、表7，8の中には、JASS等の指針類に規定された標準仕様 に反する部分も見受けられる。ここで、強度や耐久性など、構造体 としての品質に直接関係する事項については、標準的な仕様を定め これを嗱守することにより一定以上の品翼の確保を図ることも必要 である一方、床下地の表層部品質のように構造体としての品啠に直 接関係しないものの日々の居住性などに大きく影響する事項につい 
表 8 上面仕上げ作業担当者を対象とした実状調査結果

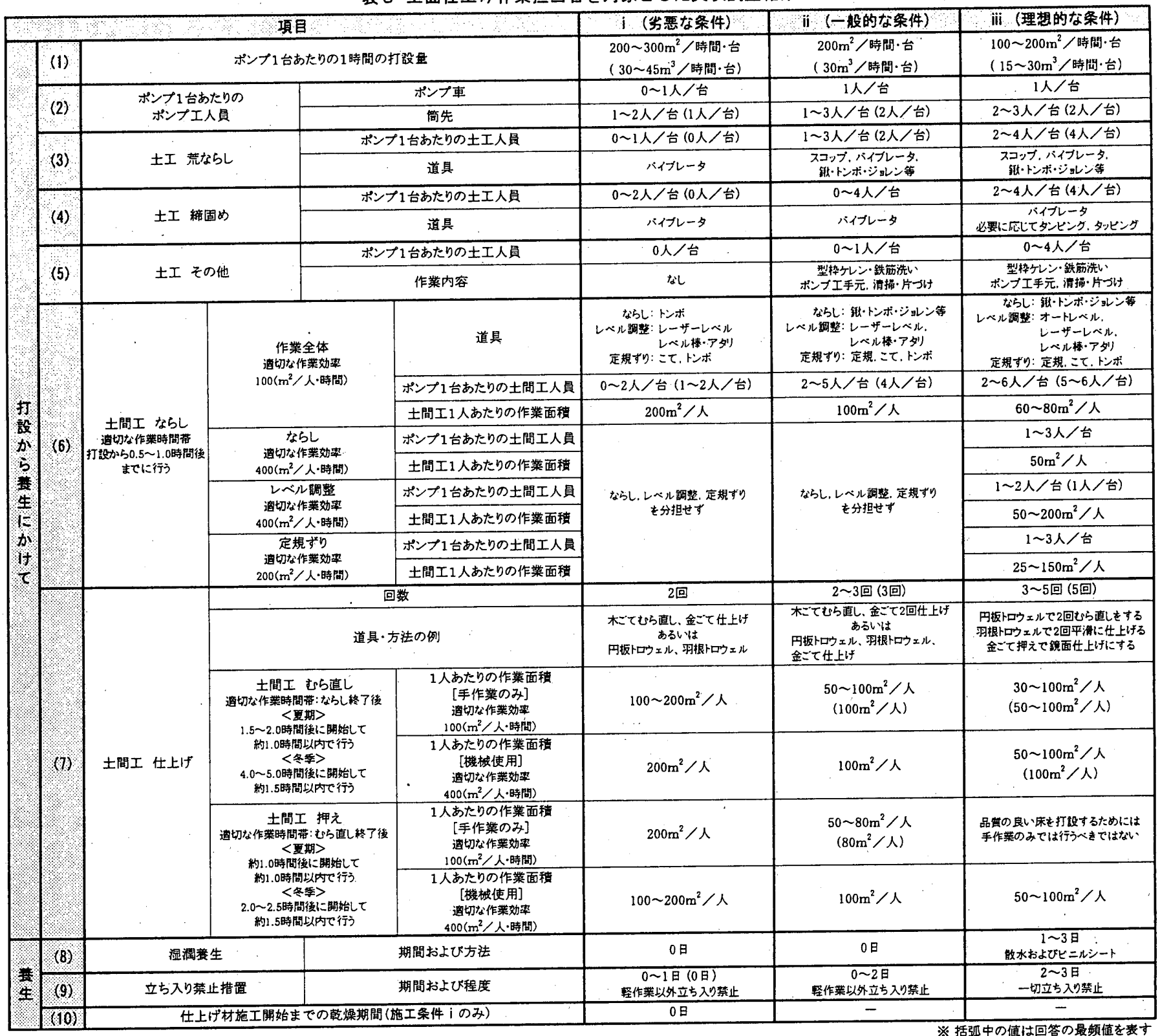

ては、要求水準に応じた品質を確保すれば良いとする性能規定の考 え方を、より導入しやすいものと考える。

\section{8. コンクリート床下地の表層部品筫に関する指摜の具体例の提示}

本節では、6.で提案したコンクリート床下地の表層部品質に関す る指標の具体例を提示した経過，結果を述べる。

具体的には、7.の調査結果を参考に数段階の施工条件を設定した うえで、上面仕上げ作業担当者を険査員とした官能検查を実施し、 陚料とした生コンを用いて床下地を施エした場合に予想される表首 部品質に関する判断を求めた。また、官能検查と並行して、試料と した生コンのスランプなどを測定し、官能検査結果との関係を、施 工条件をパラメータとして提示した。

\section{1. 官能検查概要}

官能検查の概要を表 9 に示す。検查は、試料とした生コンを検查 員に提示したうえで、表 10 に示す I N Nの4段階の施工条件を想定 し、それぞれの条件で施エした場合に予想される床下地の表層部品
質について、(1)〜5)の範ちゅうにしたがって回答を求める方法で行っ た。検查員の概要を䘚 11 に示す。表に示す通り、検查員として、 熟練上面仕上げ作業担当者6名を選定した。

ここで、想定する施工条件のうち、I〜正は、7.で述べた実状調 査結果を参考に設定したものである。すなわち、打設から養生にか けての各作業に関する条件は表 8 を、養生に関する条件は表 7 を参 考に設定した。具体的には、表 8 のおおび表 7 のの回答の中か ら比較的悪い範囲を抽出し、施工条件Iとした。また、iおよびイ から中庸な範囲を抽出し、施工条件 IIとした。さらに、iiiおよびウ から比較的良い範囲を抽出し、施工条件正とした。

一方、施工条件 IVは、通常の施工方法の範囲にとらわれず種々の 方法を駆使して、考え得る限り丁寧に施エした場合に具現される表 層部品質を把握する目的で設定したものである。

官能㭘查では、図 1 と同様の方法で、「ポンプ筒先より床上端筋上 に落ちた生コンの動き」や「バイブレータをかけたときの生コンの動 き」を再現して検查員に見せるとともに、検查員に実際に上面仕上げ 
表 9 官能険査の概要

\begin{tabular}{|c|c|c|}
\hline \multirow{2}{*}{\multicolumn{2}{|c|}{ 樦成吉る尺度 }} & 予想品筫尺度 \\
\hline & & 栬対判断による系列篹ちゅう法 \\
\hline \multirow{6}{*}{ 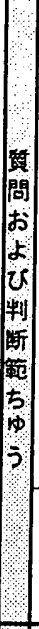 } & \multirow[t]{5}{*}{ 澌問 } & 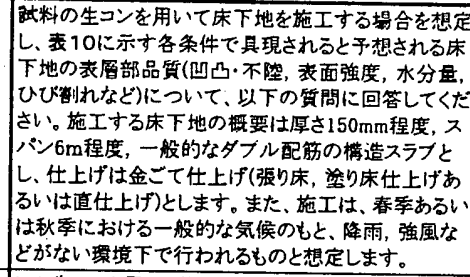 \\
\hline & & 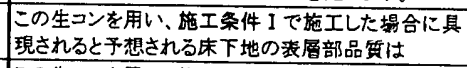 \\
\hline & & $\begin{array}{l}\text { この生コンを用い、施エ条件 ロ で施エした場合に具 } \\
\text { 現されると想される床下地の表層部品質は }\end{array}$ \\
\hline & & $\begin{array}{l}\text { この生コンを用い、施エ桑件IIIで施エした場合に具 } \\
\text { 現されると想される床下地の表層部品澌は }\end{array}$ \\
\hline & & $\begin{array}{l}\text { この生コンを用い、施工条件IVで施工した場合に具 } \\
\text { 現されると予想される床下地の表部品質は }\end{array}$ \\
\hline & $\begin{array}{c}\text { 判断 } \\
\text { 範ちゅう }\end{array}$ & 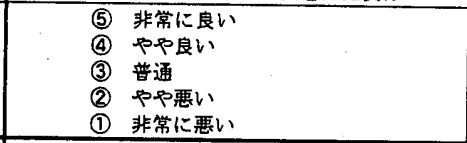 \\
\hline \multirow{7}{*}{ 模 } & 試料数 & 16種(うち2種はシャフフコン) \\
\hline & セメント & 普通ポルトランドセメント \\
\hline & 水セメント比 & $55 \%$ (シャフフコンを除く) \\
\hline & 単位水量 & 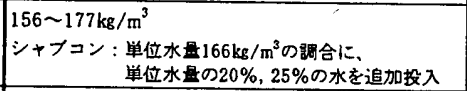 \\
\hline & 細骨材率 & $46 \%$ \\
\hline & 混和雵 & AE減水剂標梁形 \\
\hline & スランプ & $7 \times 127$ \\
\hline
\end{tabular}

作業を行わせ、回答を求めた。

試料とした生コンは、表 9 に示す16種とし、水セメント比 $55 \%$, 細骨材率 $46 \%$ で単位水量のみを変化させ、かたさを変化させた。ま た、試料のうち2種は、「シャブコン」とした。

\section{2. 官能検查経通, 䊅果}

検查は、2001年7月に実施した。検查員は、上面仕上げ作業のうち、 打設直後に行われる「ならし作業を通じて概ね予想される表層部品 質を判断し、その後の「むら直し」，「押え」作業を通じて適宜判断を 修正していた。検査員が一つの試料の判断に要した時間は、それぞ れの作業とも3分程度であった。

また、官能検査と並行して、試料とした生コンのスランプなどを、 検查員から見えない場所で測定した。

以上の要領で官能検査を実施した。表 12 に、各検査員の回答の 分散分析結果を示す。表より、主効果の分散比は高度に有意でかつ 寄与率も高いこと、個人差の分散比は有意ではあるが寄与率は主効 果と比較して非常に小さいことがわかる。このことは、試料の刺激 に十分な差がありかつ各検査員の判断に高い共通性があったこと、 および構成される尺度には検查員間に潜在する個人差が内包される

\section{表 11 官能検査の検査員の概要}

\begin{tabular}{|c|c|c|}
\hline 年觜 & 担当作嶪 & 経糇年数 \\
\hline 60 歳 & 上面仕上げ作業をはじめ左官作業全般 & 35 年 \\
\hline 51歲 & 上面仕上け作業，塗り末施工作業 & 19年 \\
\hline 64歳 & 上面仕上け作業 & 40年 \\
\hline 57歳 & 上面仕上げ作業をはじめ左官作業全般 & 37年 \\
\hline 57歳 & 上面仕上げ作業をはじめ左官作業全般 & 40年 \\
\hline 41歳 & 上面仕上げ作業 & 19 年 \\
\hline
\end{tabular}

表 12 分散分析結果

\begin{tabular}{|c|c|c|c|}
\hline & 自由度 & 分散比 & 奇与率 \\
\hline 土好果 & 63 & 14. $2^{*}$ & $61.1 \%$ \\
\hline 個 人姜 & 5 & $30.5^{*}$ & $10.1 \%$ \\
\hline
\end{tabular}

表 10 官能検查の施工条件

\begin{tabular}{|c|c|c|c|c|c|c|}
\hline \multicolumn{3}{|c|}{ 項目 } & 施工秝件 I & 施工棸件 II & 施工棸件而 & \multirow[t]{2}{*}{ 施工条件IV } \\
\hline & \multicolumn{2}{|c|}{ 生コン打殷速度 } & $\begin{array}{r}\text { ポンブ1台あたり } 300 \mathrm{~m}^{2} / \text { 時 } \\
\left(45 \mathrm{~m}^{3} / \text { 時 }\right)\end{array}$ & $\begin{array}{r}\text { ポンブ1台あたり } 200 \mathrm{~m}^{2} / \text { 時 } \\
\left(30 \mathrm{~m}^{3} / \text { 時 }\right) \\
\end{array}$ & $\begin{array}{r}\text { ホンプ1台あたり } 100 \mathrm{~m}^{2} / \text { 時 } \\
\left(15 \mathrm{~m}^{3} / \text { 時 }\right)\end{array}$ & \\
\hline & \multicolumn{2}{|c|}{ ポンプエ } & $\begin{array}{l}\text { ポンプ車:0人/台 } \\
\text { 筒先 }: \text { : 人/古 }\end{array}$ & $\begin{array}{l}\text { ポンプ車: } 1 \text { 人/右 } \\
\text { 筒先 }: 2 \text { 台 } \\
\end{array}$ & $\begin{array}{c}\text { ポンプ車: } 1 \text { 人/右 } \\
\text { 简先 }: 3 \text { 无 }\end{array}$ & \multirow{14}{*}{ 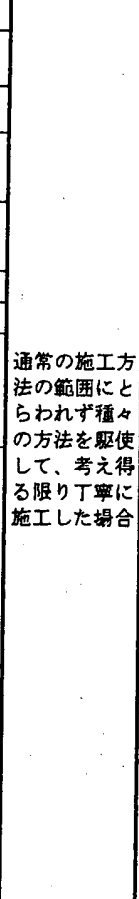 } \\
\hline & \multicolumn{2}{|c|}{ 土工 荒ならし } & \multirow{3}{*}{ 土エ人員なし } & 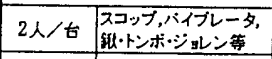 & 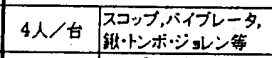 & \\
\hline \multirow{2}{*}{\multicolumn{3}{|c|}{ 土エ その他 }} & & 2 人/台 & 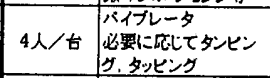 & \\
\hline & & & & 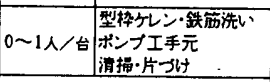 & 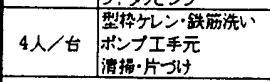 & \\
\hline \multirow{3}{*}{\multicolumn{2}{|c|}{$\begin{array}{l}\text { 土間工 } \\
\text { ならし }\end{array}$}} & 人員 & 1人/t & 4人/古 & 6 人 $/$ t & \\
\hline & & 作業面㥀 & $200 \mathrm{~m}^{2} / \lambda$ & $100 \mathrm{~m}^{2} / \lambda$ & $60 \mathrm{~m}^{2} / \curlywedge$ & \\
\hline & & 道具 & 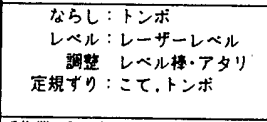 & 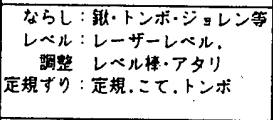 & 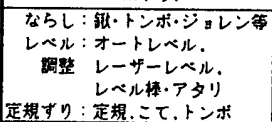 & \\
\hline \multirow{3}{*}{\multicolumn{2}{|c|}{$\begin{array}{l}\text { 土間工 } \\
\text { 仕上げ }\end{array}$}} & 方法 & 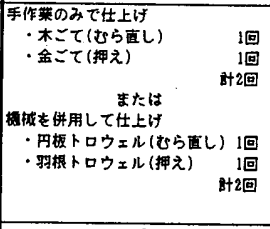 & 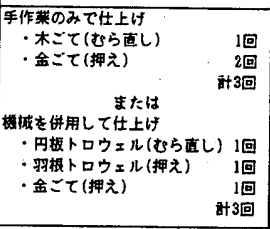 & 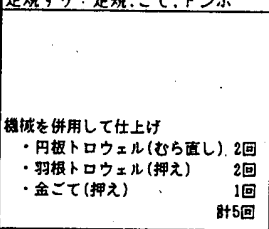 & \\
\hline & & せら直し & $200 \mathrm{~m}^{2} / \lambda$ & $100 \mathrm{~m}^{2} / \mathrm{l}$ & $50 \mathrm{~m}^{2} / \lambda$ & \\
\hline & & 押え & $200 \mathrm{~m}^{2} / 人$ & $\begin{array}{l}\text { 手作業のみ: } 80 \mathrm{~m}^{2} / \lambda \\
\text { 機械併用 }: 100 \mathrm{~m}^{2} / \lambda\end{array}$ & $50 \mathrm{~m}^{2} / 人$ & \\
\hline & \multicolumn{2}{|c|}{ 湿润養生 } & なし & なL & 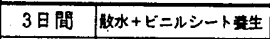 & \\
\hline \multicolumn{3}{|c|}{ 立ち入り禁止措通 } & なし & 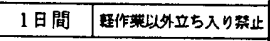 & 一切立ち入り繁止 & \\
\hline \multirow{2}{*}{\multicolumn{3}{|c|}{\begin{tabular}{|l|} 
スラプ下支保工 \\
仕上げ施工開始 \\
までの乾燥期間
\end{tabular}}} & 1800mm 間隔，7日間 設置 & 900mm 間隔，28日間 設置 & 600m 間隔, 28日間 钤置 & \\
\hline & & & なし & 21 28日間 & 28日間 & \\
\hline
\end{tabular}

ものの試料の刺激に対する共通の判断傾向が明確に反映されること を意味しており、これ以上検查員を增やしても、検查員の属性に大 きな変化がない限り、構成される尺度は大きくは変化しないことを 示唆している。

以上より、各検査員の回答に基づき、尺度構成理論5)にしたがっ て予想品質尺度を構成した。

\section{3. 表層部品質に関する指標の具体例の提示}

8. 2. で構成した予想品質尺度とスランプの関倸を、施工条件をパ ラメータとして图 5 に示す。図中の(1)〜(5)の破線は、予想品留尺度 上の判断範ちゅうの位置を示す。また、図中の点線は、目視で得ら れた対态の中心傾向を示す曲線である。

図から、以下の事項が考察できる。

（1）施工条件I〜正では、最も良好な表首部品質が得られるスラン プの範囲が存在し、それよりかたくてもやわらかくても表層部

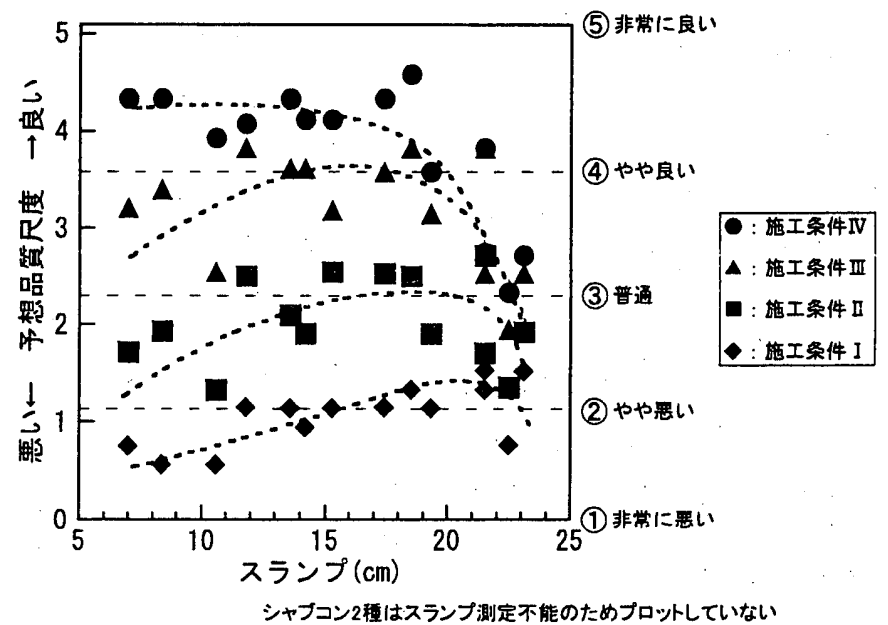

图 5 予想品算尺度とスランプの関係 （表層部品質に関する指摽の具体例） 
品質が低下している。これに対し、施工条件IVでは、あるスラ ンプよりやわらかいと表層部品質は低下するが、かたい場合は ほとんど低下せず、良好な床下地が得られると予想されている。

（2）施工条件 I 〜 II で、最も良好な表層部品質が得られるスランプ の籁囲は異なっている。すなわち：施工条件 Iでは20〜 $22 \mathrm{~cm}$ 、 II では16〜20cm、姐では15〜18cmとなっており、施工条件が良 いほどかたい方に変化している。また、それぞれのスランプ で具現される表層部品質は、施工条件 Iでは(2)やや悪い程度 に留まっているのに対し、Iでは「(3)普通」程度であり、四では 「(4) やや良い程度となっている。ちなみに、施工条件 $\mathrm{V} て ゙$ 表層 部品質が低下し始めるスランプは $15 \mathrm{~cm}$ 程度であり、このときの 品質は「(4)やや良いと「(5) 非常に良い」間となっている。

（3）（2）で述べた值よりスランブが大きい篹囲、すなわち対応曲線が 右下がりの範囲では、施工条件による表層部品質の差は比較的 小さい。これは、やわらかい生コンを使用した場合、コンクリー トそのものの品質が悪く、施工条件のいかんに関わらず同様に 表層部品質が低下すると判断されたためと思われる。なお、「シャ ブコン」の場合の表層部品質は、「(1) 非常に悪い」〜「(2) やや悪 い程度であった。

（4）（2）で述べた值よりスランプが小さい範囲、すなわち対応曲線が 左下がりもしくは水平の範囲では、施工条件が表層部品質に大 きく影響する。これは、かたい生コンを使用した場合、コンク リートそのものの品質は良いが施工が困難なために表層部品質 が低下するので、良い施工条件ほど高い表層部品質が得られる と判断されたためと思われる。

ちなみに、4.で述べた実際に現場で打設されている生コンのスラ ンプの範囲18〜22cmをこの指標と照合すると、一般的な施工条件 II の場合、得られる床下地の表層部品質は「(3)普通」程度と予想できる。 また逆に、「(4)やや良い以上の表層部品質の床下地を得るためには、 スランプ $15 \mathrm{~cm}$ よりかたい生コンを施工条件且よりも良い条件で施 エする必要があることがわかる。

以上より、コンクリート床下地の表層部品質に関する指標の具体 例として、図 5 を提示する。

ただし、提示した指標は、

・対象とした生コンおよび施工法の範囲が限定されている

縦軸に検査員の予想判断に基づく心理学的尺度を用いている

横軸としたスランプは、生コンの特性のごく一端を表すものでし かない

などの点で、無数に考えられる指標のあり姿のほんの一例にすぎな い。あくまでも、6.で提案した指標のあり方に対する理解を深める ための具体例の一つとして提示したものであることを強調する。

\section{9. おわりに}

コンクリート床下地の表層部品質に起因する問題が発生する背景 を明らかにするとともに、コンクリート床下地の表層部品質に関す る指標のあり方を提案することを目的とした本研究の結論は、以下 の通りである。

・施工管理担当者を対象とした生コンのかたさに関する実験を行 い、実際に現場で打設されている生コンの実状を把握した。その 結果、施工管理担当者が打設の際最も重要視しているのは型枠内
への充填度合いであり、このためやわらかい生コンが使用されて いる現状がうかがえた。そして、このことが、表層部品質が劣悪 な床下地が多く出現している一因となっていると想定された。

上面仕上げ作業担当者を対象に、床下地表層部の品質上の問題点 や、各問題点と施工上の原因の因果関係、およびその施工上の原 因がどのような施工条件の不備に起因するのかを、具体的に調査 した。その結果、施工にかける労力の不足や養生のための工期の 不足などの施工条件の不備が、様々な観点から表曆部の品質上の 問題点に染く関与している見状がうかがえた。

・以上の背景から、どのような特性の生コンを使用し、どのような 条件で施工すれば、どの程度の表層部品質の床下地ができるかを 定量的に示す指標が必要であることを述べ、性能の時代における 施工に必要なコンクリート床下地の指標のあり方を提案した。

、施工管理担当者および上面仕上げ作業担当者を対象に、実際の現 場におけるコンクリート床下地の施工条件の実状に関する調査を 行い、提案した指標を具体的に例示する際必要となる数段階の施 工条件を設定するための基礎資料を得た。

・かたさが異なる種々の生コンを試料とし、上面仕上げ作業担当者 を検查員とした官能検査を実施し、試料とした生コンで床下地を 施エした場合に予想される表層部品質に関する心理学的尺度を構 成した。また、この心理学的尺度と、試料とした生コンの特性の 一つであるスランプとの関係を、施工条件をパラメータとして求 め、コンクリート床下地の表層部品質に関する指標のあり方の具 体例として提示した。

\section{謝辞}

本研究のテーマ設定や方向付けなどにあたり種々御指導いただい た小野英哲先生 (東北工業大学教授, 東京工業大学名誉教授・工博) に、厚く御礼申し上げます。また、本研究に対し有益な御助言をい ただきました梶浦茂男部会長をはじめとする日本床施工技術研究協 議会第一部会の皆様、官能検查やアンケートに協力いただいた皆様 に、梁く看意を表します。

なお、実験, 解析の一部は、永富宣治氏, 中村夏子氏 (当時、東工 大横山研究室)が担当しました。

\section{参考文献}

1) 横山裕, 横井 健, 永富宣治, 中村夏子：施工管理担当者の判断に基づく フレッシュコンクリートの「かたさ」の実状，日本建筑学会大会学術諈演梗 概集A-1，pp. 783〜 784，2001年9月

2）横山 裕, 中村夏子, 横井 健: コンクリート床の品質とフレッシュコンク リートの特性および施工条件の関係（その1）予備調查さよび実態調査，日 本建築学会大会学術講演梗概集A-1，pp. 785〜 786，2001年9月

3）横山裕, 中村夏子, 横井健 : コンクリート床の品質とフレッシュコンク リートの特性および施工条件の関倸(その2) 品質予测判断実験および施工 性の評価指標, 日本建筑学会大会学術講演梗概集A-1, pp. 787 788, 2001年 9月

4）添田智美，小野英哲，地港茂雄：床下地コンクリート施工における適正な計 画, 管理の重要性確認のための調査, 実験 コンクリート床下地表首部分の 欠陷を媒体として, 日本建築学会大会学術丵演梗概集A-1, pp. 1145 1146, 1998年9月

5）J.P. Guilford 著，秋重 義治 監訳：精神测定法，培風館，1959年9月

(2003年 9 月 9 日原稿受理, 2004 年 3 月 1 日採用決定) 